\title{
The World Health Organization's mechanisms for increasing the health sector budget: The South African context
}

\author{
F H J Venter, MCom (Economics), DPH; J E Wolvaardt, BCur, MPH, PGCHE, PhD \\ School of Health Systems and Public Health, Faculty of Health Sciences, University of Pretoria, South Africa
}

Corresponding author: F H J Venter(fouche.venter@dnaeconomics.com)

\begin{abstract}
South Africa (SA) has limited scope for raising income taxes, and the proposed National Health Insurance (NHI) scheme will necessitate growth in the health sector budget. The NHI White Paper suggests five funding scenarios to meet the expected shortfall. These scenarios are a mixture of a surcharge on taxable income, an increase in value-added tax and a payroll tax. Five alternative options, suggested by the World Health Organization, are interrogated as ways to decrease the general taxation proposed in the White Paper. The five mechanisms (corporate tax, financial transaction levy, and taxes on tobacco, alcohol and unhealthy foods) were chosen based on their fund-raising potential and their mandatory element. A literature review provides the information for a discussion of the potential costs of each mechanism. Within specific assumptions, potential budgetary contribution is compared with the requirement. First, raising corporate tax rates could raise enough funds, but the losses due to capital flight might be too much for the local economy to bear. Second, a levy on currency transactions is unlikely to raise the required resources, even without a probable decrease in the number of transactions. Third, the increase in the tax on tobacco and alcohol would need to be very large, even assuming that consumption patterns would remain unchanged. Lastly, a tax on unhealthy food products is a new idea and could be explored as an option - especially as the SA Treasury has announced its future implementation. Implementing only one of the mechanisms is unlikely to increase available funding sufficiently, but if they are implemented together the welfare-maximising tax rate for each mechanism may be high enough to fulfil the NHI scheme's budgetary requirement, moderating the increases in the tax burden of the SA population.
\end{abstract}

S Afr Med J 2016;106(8):771-774. DOI:10.7196/SAMJ.2016.v106i8.10654

The World Health Organization (WHO)'s 2010 report on health systems financing for universal health coverage ${ }^{[1]}$ proposed various innovative mechanisms for raising additional resources for health. These proposals were primarily based on a background paper by Stenberg et al..$^{[2]}$ on the same topic, in which each of the options was ranked according to its fund-raising potential.

South Africa (SA) is currently in the process of implementing a National Health Insurance (NHI) scheme. The resource requirement for implementation of this scheme is substantial, and the NHI White Paper (hereinafter referred to as 'the White Paper') outlines five scenarios to meet the middle-ground projected shortfall of ZAR71.9 billion (2010 prices) by 2025/26. ${ }^{[3]}$ Very little information about the factors and assumptions that were taken into account, such as medical inflation and changes in disease profile, is provided in the White Paper.

Scenario A includes the introduction of a payroll tax, a surcharge on taxable income and increases in the rate of value-added tax (VAT). Scenario B utilises a combination of the surcharge with a payroll tax, while scenario $C$ is a combination of a surcharge on taxable income with an increase in VAT. Scenario D is a payroll tax with a surcharge on taxable income, while scenario $\mathrm{E}$ is a surcharge on taxable income only. Four of the five scenarios include a surcharge on taxable income, and all five scenarios include percentage increases spread over the time period. ${ }^{[3]}$ However, these are not the only options available. The White Paper also elaborates on excise duties on alcohol and tobacco products, reallocation of medical scheme funding and the proposed carbon tax as potential sources of NHI funding.

This article considers excise duties on alcohol and tobacco products along with the various other low-medium, medium, mediumhigh and high potential fund-raising options, without a voluntary element, as defined and proposed by the WHO, and reviews each in the SA context. Stenberg et al. ${ }^{[2]}$ used various methods to calculate the potential of each option to generate additional resources for the health system. Where possible, this article uses these methods or methods of its own to estimate the increase in the health budget that could potentially result from the implementation of the mechanisms. These elementary calculations assume no change in economic or social behaviour.

The result of the calculations is compared with the average yearly increase required by the NHI. The comparison is based on the assumption that the mechanism was implemented in 2010 and that the proceeds from the mechanism are earmarked for the health sector. Possible costs or negative effects of the mechanism's implementation in SA are extrapolated from the literature.

\section{Health sector funding requirement}

The White Paper states that the requirements for health (in real 2010 financial terms) will increase from ZAR109.8 billion in 2010 to ZAR255.8 billion in 2025/26, the proposed roll-out period of the scheme. ${ }^{[3]}$ In addition to this estimation, McIntyre ${ }^{[4]}$ modelled the resource requirements for three health financing reforms, one of which involves pursuing universal health coverage through an NHI scheme. Estimations varied widely depending on assumptions, but her 'best guess' scenario increased health resource requirements from state funding to ZAR295 billion by 2025 (2010 prices). ${ }^{[4]}$

Fig. 1 illustrates the gap between the funding requirement necessitated by NHI implementation (solid line) and the projected funding (dashed line). The projected funding assumes that the budget allocated to the health sector increases at the White Paper's middle-ground funding scenario rate of $3.5 \%$ between 2010 and 2025. Even though 
the White Paper assumes that this is its most likely scenario, a GDP growth rate of $3.5 \%$ seems optimistic. In the recently published statement by the South African Reserve Bank's Monetary Policy Committee, it is stated that GDP growth in 2015 was a mere $1.3 \%$ and that growth of only $0.8 \%$, $1.4 \%$ and $1.8 \%$ is expected for 2016, 2017 and 2018, respectively. ${ }^{[5]}$ Given this weak economic outlook, it is possible that even the White Paper's most pessimistic annual funding growth scenario, in which funding to the health sector grows by only $2 \%$, could be a challenge to achieve. Nevertheless, given the information currently available, we thought it was most appropriate to remain in line with the White Paper and base our calculations on its middle-ground scenario of $3.5 \%$. All calculations in this article have been adjusted for inflation using 2010 as the base year.

For the funding requirement, the prediction provided by the White Paper is used. This is a conservative estimate when compared with that of McIntyre, ${ }^{[4]}$ and is that the SA health budget should grow to ZAR255.8 billion by $2025{ }^{[3]}$

The White Paper predicts various shortfalls in 2025/26 based on various specific health funding growth over the period ZAR71.9 billion if the baseline resources increase by $3.5 \%$ per year (Fig. 1), ZAR27.6 billion if baseline resources increase by $5.0 \%$ per year, and finally ZAR108 billion if baseline resources grow by $2.0 \%$ per year. Rather than looking at the shortfall in $2025 / 26$, this article calculates the cumulative shortfall under the $3.5 \%$ growth scenario over the 15-year period between 2010/11 and 2025/26, the NHI implementation period. This allowed us to calculate an average percentage shortfall for each year within the period and compare this value with the potential funding contribution for each of the instruments under review.

The shortfall, represented by the space between the solid and dashed lines in Fig. 1, aggregates to ZAR378.5 billion over the 15 years. This cumulative shortfall represents $16.4 \%$ of the cumulative funding projection over the same period, implying that if the funding, as projected by the $3.5 \%$ growth scenario, was and is increased by a further $16.4 \%$ each year between 2010 and 2025, the cumulative funding would equal the required cumulative expenditure over the implementation period. The five tax scenarios outlined by the White Paper are an attempt to address the shortfall, and this article explores the feasibility of using innovative finance mechanisms to moderate the size of the probable surcharge on taxable income - an inclusion in four of the five tax scenarios.

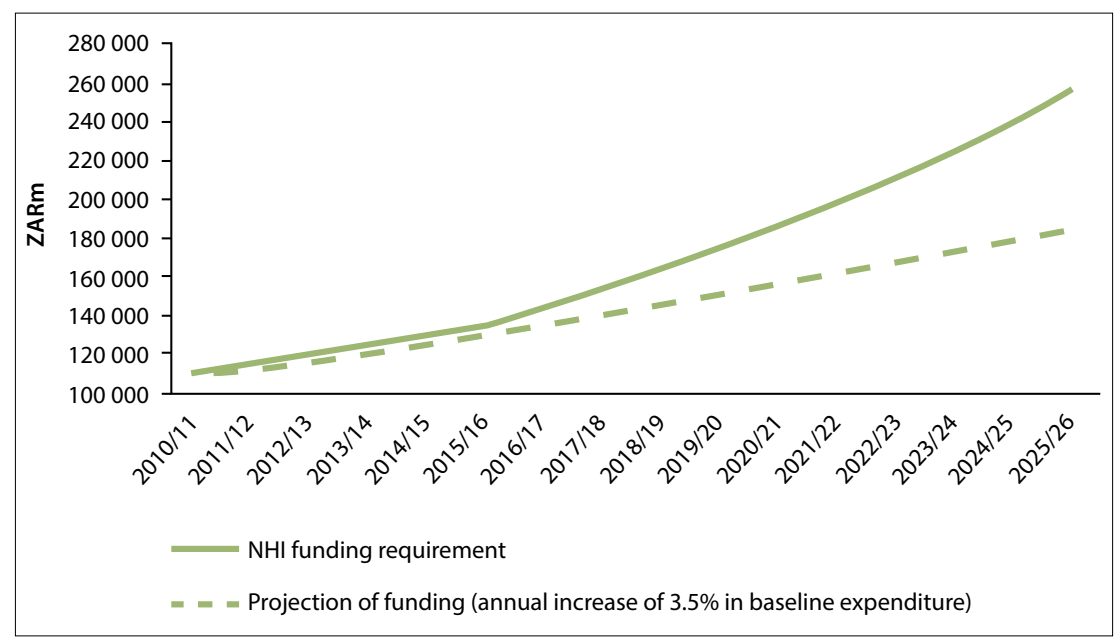

Fig. 1. Projected funding gap (2010 prices). ${ }^{[2]}$

\section{The options}

Recognising the additional resources required for universal healthcare, the WHO proposed 13 options for increasing funding for health. For this article, the options categorised as having a low fundraising potential as well as those with a voluntary or charity element have been disregarded. ${ }^{[2]}$ Only increasing corporate taxes, imposing sectorspecific corporate taxes, imposing a levy on currency transactions, increasing excise duties on alcohol and tobacco products and imposing excise duties on unhealthy foods will therefore be discussed.

\section{Corporate tax}

Corporate tax differentials, or a country's corporate tax rate relative to countries with which it competes for investment, are more important than the absolute level. ${ }^{[6,7]}$ SA's top marginal corporate income tax rate is currently $28 \%$, with lower rates applying to smaller businesses. ${ }^{[8]}$ When compared with Brazil, Russia, China and India, SA's corporate income tax rate is in the middle of the range (Table 1).

Diamond et al. ${ }^{[7]}$ point out the negative economic effects of a relatively high corporate tax rate in the USA compared with other developed countries, i.e. an outflow of capital and a consequent reduction in productive capacity. In a study on the Organisation for Economic Co-operation and Development countries, Johansson et al. ${ }^{[9]}$ label corporate income taxes as more harmful to economic growth than any other tax.

Compared with the other BRICS (Brazil, Russia, China, India and SA) countries, SA may have some space for an increase in corporate taxation. However, following the abolishment of the Secondary Tax on Companies on 1 April 2012, ${ }^{[10]}$ it is unlikely that government would have an appetite for
Table 1. Corporate tax rates for BRICS member countries (current on 1 January 2015) ${ }^{[10]}$

\begin{tabular}{ll}
\hline Country & $\begin{array}{l}\text { Top marginal corporate } \\
\text { income tax rate }\end{array}$ \\
\hline India & $34 \%$ \\
Brazil & $34 \%$ \\
SA & $28 \%$ \\
China & $25 \%$ \\
Russia & $20 \%$ \\
BRICS = Brazil, Russia, China, India and SA.
\end{tabular}

such a policy move. In the 2013/14 financial year, corporate tax revenue in SA amounted to ZAR177.3 billion, ${ }^{[11]}$ or ZAR151.3 billion at constant 2010 prices. ${ }^{[12]}$ Covering the NHI shortfall (16.4\%) during that year would have required a $13.2 \%$ increase in total revenue from corporate income taxation.

The WHO report does not suggest an increase in the taxation rate for all companies, but rather for the most profitable. If the shortfall is to be financed by an increase in the corporate tax rate of specific industries instead of all industries, the magnitude of the increase per company would have to be greater. The economic effects resulting from higher relative corporate tax rates that Diamond et al. ${ }^{[7]}$ discuss could be magnified or diminished in these industries. Because of their higher profits, such companies might be able to absorb a greater tax shock, resulting in a subsequent smaller macroeconomic impact. However, if tax rate increases are too severe, capital flight from these profitable industries would lead to comparatively worse economic effects. Further research should be done to estimate the corporate tax rate threshold of SA's most profitable industries and determine whether this could 
be high enough to significantly affect the NHI budget shortfall without leading to severe macroeconomic consequences.

\section{Levies on financial transactions/instruments}

Stenberg et $a l .{ }^{[2]}$ provide several examples of how financial transactions can be utilised to raise more revenue for health, e.g. Argentina taxes current account debits and credits, Brazil taxes bank withdrawals and earmarks the revenue for its public health sector, and Zambia has a levy on all gross interest earned on any savings or deposit accounts, treasury bills, government bonds or other financial instruments. In addition, the issuing of diaspora bonds in some countries such as India, Israel and Sri Lanka is mentioned as a mechanism to raise revenue for health. ${ }^{[2]}$ This article reviews the possibility of raising additional funds in SA through a levy imposed on currency transactions.

Currency transactions are any transactions in which the buying and/or selling of foreign currency for domestic currency are involved. Stenberg et al.$^{[2]}$ mention that most discussions involving the imposition of a currency transaction levy have focused on imposing such a levy in high-income countries, and then distributing these funds to lowerincome countries. The number of these transactions is relatively low in lower-income countries compared with high-income countries, and the assumption is that the costs might outweigh the benefits when such levies are imposed in lower-income countries. The associated costs include increased market volatility, increased economic uncertainty, ${ }^{[13]}$ and a decrease in the number of transactions due to the levy, ${ }^{[14]}$ a pivotal element of any economy. ${ }^{[2]}$ There is also significant debate around the technical and political feasibility of such a tax, as it has been posited that it is relatively easy to evade through market migration to offshore tax havens or to avoid through asset substitution. ${ }^{[15]}$ Schmidt ${ }^{[16]}$ used an increase in the spread between the bid and ask price in the dollar/yen currency market between 1986 and 2006 as a proxy for the imposition of such a tax. It was found that a $1 \%$ increase in the spread caused a $0.43 \%$ decrease in the volume of currency transactions. ${ }^{[16]}$

The methodology applied to India described by Stenberg et $a l .{ }^{[2]}$ is now applied to SA. SA, although a smaller economy, still managed USD21 billion daily turnover (current prices) from currency transactions in 2013. ${ }^{[17]}$ If the WHO's High Level Taskforce for Innovative International Financing suggestion of a $0.005 \%$ levy on annual turnover ${ }^{[18]}$ had been accepted in SA, ZAR2.9 billion worth of revenue (2010 prices and average 2013 exchange rate of ZAR9.65 ${ }^{[19]}$ per USD) could have been added to the SA revenue pool in 2013. It can, however, be expected that this amount would be slightly lower, as the imposition of the tax would also lead to fewer daily currency transactions and therefore less daily turnover. Even if there was, unrealistically, no decrease in the number of transactions and the entire amount of revenue raised by the levy had been earmarked for the health sector in 2013, the levy would have been able to decrease the shortfall by $14.5 \%$ from ZAR20 billion to ZAR17.1 billion. ${ }^{[20]}$ It is clear that that even under the best circumstances, a tax on currency transaction would only be able to reduce the shortfall marginally on its own.

\section{Excise taxes on products harmful to health}

The harmful side-effects of tobacco consumption (e.g. neoplastic, vascular and respiratory diseases, ${ }^{[21]}$ cancer, abdominal aortic aneurysms and cataracts ${ }^{[22]}$ ) and excessive alcohol consumption (e.g. infectious diseases, stroke, cancer, diabetes, neuropsychiatric diseases, liver and pancreatic disease ${ }^{[23,24]}$ ) are well documented. In fact, research has shown that tobacco and alcohol are the second and third largest contributors, respectively, to the global disease burden and together cause nearly $12 \%$ of the world's disability-adjusted lifeyears. There is therefore a rational reason for the widespread advocacy for the imposition of excise duties on alcohol and tobacco products, as it has been shown that these duties can decrease consumption and subsequently decrease the disease burden. ${ }^{[25,26]}$

In SA, specific excise duties on alcohol and tobacco contributed $3.2 \%$ to total tax revenue in $2013 / 14$, or approximately ZAR24.7 billion (constant 2010 prices). ${ }^{[12]}$ If SA had increased the revenue generated from these taxes and earmarked the increased revenue to the health sector to cover the NHI shortfall in 2013/14, it would have had to increase tax revenue from excise duties on alcohol and tobacco by $80.8 \%{ }^{[6]}$ Given the effect that an increase in the tax rates would have on demand in the formal market for these goods, on average, the tax rates themselves would have had to be increased by even more than $80.8 \%$.

Stenberg et al..$^{[2]}$ also suggest a tax on unhealthy food. This can be done through increased VAT on foods that are high in fat or sugar, or a specific tax per unit on unhealthy products such as carbonated sugary beverages, sweets, ice cream, etc. ${ }^{[2]}$ The most widely advocated instrument, which SA is in the process of implementing, is a specific tax on sugar-sweetened beverages. Similar to alcohol and tobacco, the side-effects of excessive consumption of these products can be severe and include obesity, diabetes, coronary heart events and strokes. ${ }^{[27,28]}$

The rationale for excise duties on unhealthy products is therefore similar for all products. The price elasticity of demand for alcohol ${ }^{[29-31]}$ and tobacco ${ }^{[29,31]}$ is traditionally relatively low, ${ }^{[31,32]}$ meaning that the imposition of a tax can contribute substantially to the total revenue pool. ${ }^{[2]}$ The price elasticity of demand for unhealthy food products varies more widely, depending on the substitutability of the product. ${ }^{[31]}$ If the tax is high enough to affect consumption, the health benefits from decreased consumption are able to decrease the health budget requirement. ${ }^{[31]}$ The tax rate should therefore be set in such a way that this twofold benefit maximises societal welfare. ${ }^{[2]}$

The imposition of specific excise taxes on harmful products has two major counter-arguments. The first of these relates to their potential to increase smuggling and the size of the illicit market. ${ }^{[33,34]}$ This argument is specifically related to tobacco, although research shows that the size of this market and the effects of the tax are often overstated by the tobacco industry. ${ }^{[3,35,36]}$ Nevertheless, commenting on the illicit cigarette market in SA, Van Walbeek ${ }^{[37]}$ states that the 'Illicit tobacco trade is a problem and should be taken seriously'. Research shows that until 2010 there was no evidence that the market for illicit cigarettes had increased, ${ }^{[33]}$ despite a significant increase in the real tax per cigarette packet in SA from 1993 onwards. ${ }^{[33]}$ The alcohol sector industries in SA have often argued against increases in excise taxes by noting the potential for increased illicit liquor consumption. ${ }^{[38,39]}$

Even though taxes on unhealthy foods will not lead to an increase in illicit trade, the regressivity of excise taxes on these foods along with alcohol and tobacco ${ }^{[40-44]}$ is worth debate. With an ever-increasing Gini coefficient (0.66 in 1993 and 0.7 in 2008), SA is one of the most economically unequal societies in the world. ${ }^{[45]}$ For this reason, special caution is necessary when considering a tax with regressive effects.

In terms of the tax on unhealthy food, there are ways of circumventing the regressive effects of the tax by subsidising healthier options. ${ }^{[41]}$ It must be kept in mind, however, that the revenue raised by the tax on unhealthy food can be negated by the subsidy on healthier options.

\section{Discussion}

The White Paper has a specific focus on payroll taxes, surcharges on taxable income and increases in VAT as fiscal instruments that could cover the funding shortfall caused by the implementation of NHI. It also provides some discussion on current employer contributions to medical 
schemes being reallocated to the NHI fund, the current tax credit for medical scheme membership being scaled down, and the potential utilisation of the carbon tax in the health sector. No specific estimation of the size of the effect that these actions might have on the shortfall is provided, and further research into this area is strongly recommended.

This article reviewed various funding options, other than those already under consideration, that are available to the SA government to raise additional resources for its health sector.

Raising corporate taxation could raise enough funds, but the losses due to capital flight might be too much for the SA economy to bear. The increase would therefore have to be moderate, and it is unlikely that a welfare-maximising corporate tax rate could raise sufficient government income, especially if only specific companies or industries are targeted. A financial transaction tax, specifically a levy on currency transactions, is also unlikely to raise the required resources on its own, even without a likely decrease in the number of transactions. Finally, the required increase in the tax on tobacco and alcohol would have to be very large, even when assuming that consumption patterns would remain unchanged. The imposition of a tax on unhealthy food products is a very new idea and something that could be explored further as an option for SA. Nevertheless, the problem with excise duties is their regressivity which is a specific problem for a country as economically unequal as SA.

Yates ${ }^{[46]}$ has identified progressive taxes as key to financing a health system's striving towards universal health coverage. The premise would therefore promote increases in corporate taxes ${ }^{[46]}$ and levies on financial transactions, ${ }^{[47]}$ and discount taxes on tobacco, alcohol and unhealthy foods. Nevertheless, regressivity is not the only cost associated with the imposition of these fund-raising mechanisms, and the increase in the tax revenue would have to be weighed against these costs for each mechanism.

The White Paper clearly outlines five scenarios for revenue generation, all of which are combinations of more than a single source. If more mechanisms are used, less tax will have to be collected from each one, increasing the possibility that $\mathrm{SA}$ will be able to collect more tax revenue for the health sector without compromising the rest of the economy. All tax mechanisms have associated administrative costs, ${ }^{[4,49]}$ which also have to be taken into account when deciding on how many mechanisms should be implemented.

\section{Conclusion}

The calculations in this article make very strong assumptions and should by no means be confused with modelling. They are merely utilised as devices to illustrate to the reader the massive task that is set before the SA National Treasury to finance the implementation of the NHI scheme. The current scenario that makes use of the most sources of income (surcharge on taxable income, VAT increase and a payroll tax) has implications for the working population, the poor and employers. This article has outlined additional mechanisms to modify the burden on the average South African.

\footnotetext{
1. World Health Organization. Health Systems Financing: The Path to Universal Coverage. Geneva: World Health Organization, 2010

2. Stenberg K, Elovainio R, Chisholm D, et al. Responding to the Challenge of Resource Mobilization Mechanisms for Raising Additional Domestic Resources for Health. Geneva: World Health Organization, 2010. http://www.who.int/healthsystems/topics/financing/healthreport/13Innovatived omfinancing.pdf (accessed 4 February 2016).

3. National Department of Health, South Africa. National Health Insurance for South Africa: Towards 3. National Department of Health, South Africa. National Healt
Universal Health Coverage. Version 40. Pretoria: $\mathrm{NDoH}, 2015$.

4. McIntyre D. Health Service Financing for Universal Coverage in East and Southern Africa. EQUINET 4. McIntyre D. Health Service Financing for Universal Coverage in East and Southern Africa.
Discussion Paper 95. Cape Town: Health Economics Unit, University of Cape Town, 2012.

5. South African Reserve Bank: Monetary Policy Committee. Press Statement Embargo Delivery. Statement of the Monetary Policy Committee. 2016. https://www.resbank.co.za/Lists/News\%20and\%20Publications/ Attachments/7223/MPC\%20Statement\%2017\%20March\%202016\%20.pdf (accessed 5 June 2016).

6. Bénassy-Quéré A, Fontagné L, Lahrèche-Révil A. How does FDI react to corporate taxation? Int Tax Public Finance 2005;12(5):583-603. DOI:10.1007/s10797-005-2652-4

7. Diamond J,Zodrow G, Carroll R. Macroeconomic Effects of Lower Corporate Income Tax Rates Recently Enacted Abroad: Report Prepared for the Reforming America's Taxes Equitably (RATE) Coalition. Washington, DC: Ernst \& Young, 2013. http://ratecoalition.com/wp-content/uploads/2013/04/EY TPA_RATE_Coalition_Macroanalysis_2013_03_04_FINAL.pdf (accessed 2 September 2015).
}

8. South African Revenue Services. Tax Pocket Guide. Pretoria: National Treasury, 2015. http://www. treasury.gov.za/documents/national\%20budget/2015/defaultaspx (accessed 15 July 2015).

9. Johansson Å, Heady C, Arnold J, et al. Taxation and Economic Growth. OECD Economics Department 9. Johansson A, Heady C, Arnold, et al. Taxation and Economic Growth. OECD F

10. Ernst and Young. Worldwide Corporate Tax Guide. London: Ernst \& Young, 2015:175, 256, 586, 1184, Ernst and Young. Worldwide Corporate Tax Guide. London: Ernst \& Young, 2015:175, 256, 586, 1184,
1284 . http://www.ey.com/Publication/vwLUAssets/Worldwide_corporate_tax_guide_2015/\$FILE/ 1284. http://www.ey.com/Publication/vwLUAssets/Worldwide_corporate_tax

11. National Treasury. Budget Review. Pretoria: National Treasury, 2015. http://www.treasury.gov.za/ documents/national\%20budget/2015/review/default.aspx (accessed 10 June 2015).

12. Statistics South Africa. P0141 - Consumer Price Index (CPI). Pretoria: SSA, 2015:4. http://www. statssa.gov.za/?page_id =1854\&PPN=P0141\&SCH=6037 (accessed 1 August 2015).

13. McCulloch N, Pacillo G. The Tobin tax: A review of the evidence. IDS Research Reports 2011;2011(68):1-77. DOI:10.1111/j.2040-0217.2011.00068_2.x

14. Wang GHK, Yau J. Would a Financial Transaction Tax Affect Financial Market Activity? Insights from Future Markets (July 9, 2012). Washington, DC: Cato Institute Policy Analysis, 2012. http://ssrn.com/ abstract=2226961 (accessed 3 February 2016).

15. Nissanke M. Revenue potential of the currency transaction tax for development finance: A critical appraisal. WIDER Discussion Papers/World Institute for Development Economics (UNU-WIDER), No. 2003/81, 2003. http://hdl.handle.net/10419/53109 (accessed 3 February 2016).

16. Schmidt R. The Currency Transaction Tax: Rate and Revenue Estimates. Ottawa: North-South Institute, 2007.

16. Schmidt R. The Currency Transaction Tax: Rate and Revenue Estimates. Ottawa: North-South Institute, 2007. 7. Bank for International Settlements: Monetary and Economic Department. Triennial Central Bank Survey. B
Bank for International Settlements, 2013:14. http://www.bis.org/publ/rpfxi3fx.pdf (accessed 15 July 2015).

18. World Health Organization. Constraints to Scaling up the Health Millennium Development Goals: Costing and Financial Gap Analysis. Background Document for the Taskforce on Innovative International Financing for Health Systems. Geneva: WHO, 2010.

19. Nedbank Group. Exchange rates - annual averages from 1995. Nedbank Group, 2015. http://www.nedbankgroup. co.za/pdfs/economic/exchangeRates/Annual_Average_for_Knet_2015.pdf (accessed 27 August 2015).

20. National Treasury. National Budget Review. Pretoria: National Treasury, 2014. http://www.treasury. gov.za/documents/national\%20budget/2014/default.aspx (accessed 10 June 2015).

21. Jha P, Ramasundarahettige C, Landsman V, et al. 21st-century hazards of smoking and benefits of cessation in the United States. N Engl J Med 2013;368(4):341-350. DOI:10.3410/f.717973072.793473561

22. US Department of Health and Human Services. The Health Consequences of Smoking: A Report of the Surgeon General. Atlanta, Ga: US Department of Health and Human Services, Centers for Disease Control and Prevention, National Center for Chronic Disease Prevention and Health Promotion, Office on Smoking and Health, 2004.

23. Rehm J. The risks associated with alcohol use and alcoholism. Alcohol Res Health 2011;34(2):135-143.

24. World Health Organization. Global Status Report on Alcohol and Health. Geneva: WHO, 2014.

25. Salti N, Chaaban J, Nakkash R, Alaouie H. The effect of taxation on tobacco consumption and public revenues in Lebanon. Tob Control 2015;24(1):77-81. DOI:10.1136/tobaccocontrol-2012-050703

26. Xu X, Chaloupka FJ. The effects of prices on alcohol use and its consequences. Alcohol Res Health 2011;34(2):236

27. Wang YC, Coxson P, Shen YM, Goldman L, Bibbins-Domingo K. A penny-per-ounce tax on sugarsweetened beverages would cut health and cost burdens of diabetes. Health Aff 2012;31(1):199-207. DOI:10.1377/hlthaff.2011.0410

28. Blecher E. Taxes on tobacco, alcohol and sugar sweetened beverages: Linkages and lessons learned. Soc Sci Med 2015;136:175-179. DOI:10.1016/.j.socscimed.2015.05.022

29. Diaz MC, Chaloupka FJ, Jernigan DH. The Effects of Alcohol Excise Tax Increases on Public Health and Safety in Texas. Texans Standing Tall, 2 March 2015. http://texansstandingtall.org/pdfs/15_ Alcohol_ExciseReport.pdf (accessed 4 July 2016).

30. Daley JI, Stahre MA, Chaloupka FJ, Naimi TS. The impact of a 25 -cent-per-drink alcohol tax increase. Am J Prev Med 2012;42(4):382-389. DOI:10.1016/j.amepre.2011.12.008

Am J Prev Med 2012;42(4):382-389. DOI:10.1016/j.amepre.2011.12.008
31. Sassi F, Belloni A, Capobianco C, Alemanno A. Taxation and Economic Incentives on Health-Related Cossi F, Belloni A, Capobianco C, Alemanno A. Taxation and Economic Incentives on Health-Related
Commodities: Alcohol, Tobacco and Food. HEC Paris Research Paper No. LAW-2014-1038. Cambridge: Cambridge University Press, 2014. http://ssrn.com/abstract=2400930 (accessed 4 February 2016).

32. Chaloupka FJ, Yurekli A, Fong GT. Tobacco taxes as a tobacco control strategy. Tob Control 2012;21(2):172-180. DOI:10.1136/tobaccocontrol-2011-050417

33. Van Walbeek C, Shai L. Are the tobacco industry's claims about the size of the illicit cigarette market credible? The case of South Africa. Tob Control 2015;24(e2):e142-e146. DOI:10.1136/ tobaccocontrol-2013-051441

34. Cooper A, Witt D. The linkage between tax burden and illicit trade of excisable products: The example of tobacco. World Customs J 2012;6(2):41-58

35. Chen J, McGhee SM, Townsend J, Lam TH, Hedley AJ. Did the tobacco industry inflate estimates of illicit cigarette consumption in Asia? An empirical analysis. Tob Control 2015;24(e2):e161-e167. DOI:10.1136/tobaccocontrol-2014-051937

36. Stoklosa M, Ross H. Contrasting academic and tobacco industry estimates of illicit cigarette trade: Evidence from Warsaw, Poland. Tob Control 2014;23(e1):e30-e34. DOI:10.1136/tobaccocontrol-2013-051099

37. Van Walbeek C. Measuring changes in the illicit cigarette market using government revenue data: The example of South Africa. Tob Control 2014;23(el):e69-e74. DOI:10.1136/tobaccocontrol-2013-051178

38. Babor TF, Robaina K, Jernigan D. The influence of industry actions on the availability of alcoholic beverages in the African Region. Addiction 2015;110(4):561-571. DOI:10.1111/add.12832

39. Parry C, London L, Myers B. Delays in South Africa's plans to ban alcohol advertising. Lancet 2014;383(9933):1972. DOI:10.1016/s0140-6736(14)60954-5

40. Monkan N, Woolard I, Ajam T. The tax system and inclusive growth in South Africa: Towards an analytical framework for the Davis Tax Committee. Pretoria: Davis Tax Committee, 2015. http:// www.taxcom.org.za/docs/20150605\%20DTC\%20Macro\%20Analysis\%20Framework\%20First\%20 Interim\%20Report \%20(Full)\%20\%20for\%20public\%20comment.pdf (accessed 1 August 2015).

41. López-Casasnovas G, Gil J, Mora T. Taxation of unhealthy consumption of food and drinks: An updated literature review. Hacienda Pública Española/Review of Public Economics 2013;207(4/2013):119-140. DOI:10.7866/hpe-rpe.13.4.5

42. Hoffer A, Gvillo R, Shughart II WF, Thomas MD. Regressive Effects: Causes and Consequences of Selective Consumption Taxation. Arlington, Va: Mercatus Center at George Mason University, 2015.

3. Ataguba JE. Alcohol policy and taxation in South Africa. Applied Health Econ Health Policy 2012:10(1):65-76. DOI:10.2165/11594860-000000000-00000
2015

44. Mytton OT, Clarke D, Rayner M. Taxing unhealthy food and drinks to improve health. BMJ 2012;344:e2931. DOI:10.1136/bmj.e293

45. Hvistendahl M. While emerging economies boom, equality goes bust. Science 2014;344(6186):832835. DOI:10.1126/science. 344.6186 .832

46. Yates R. Universal health coverage: Progressive taxes are key. Lancet 2015;386(9990):227-229. DOI:10.1016/s0140-6736(15)60868-6

47. Schäfer D, Schulmeister S, Vella J, Masciandaro D, Passarelli F, Buckley RP. The financial transaction tax - boon or bane? Intereconomics 2012;47(2):76-103. DOI:10.1007/s10272-012-0409-8

48. Auriol E, Warlters M. The marginal cost of public funds and tax reform in Africa. J Dev Econ 2012;97(1):58-72. DOI:10.1016/j.jdeveco.2011.01.003

49. Dharmapala D, Slemrod J, Wilson JD. Tax policy and the missing middle: Optimal tax remittance with firm-level administrative costs. J Public Econ 2011;95(9):1036-1047. DOI:10.2139/ssrn.1138015

Accepted 2 June 2016. 